\title{
Amphibians of Vassununga State Park, one of the last remnants of semideciduous Atlantic Forest and Cerrado in northeastern São Paulo state, Brazil
}

\author{
Ronildo Alves Benício ${ }^{1, *}$ \& Fernando Rodrigues da Silva ${ }^{2}$ \\ 'Programa de Pós Graduação em Ecologia e Recursos Naturais, Universidade Federal de São Carlos, \\ São Carlos, SP, Brazil. \\ ${ }^{2}$ Laboratório de Ecologia Teórica: Integrando Tempo, Biologia e Espaço (LET.IT.BE), Departamento de Ciências \\ Ambientais, Universidade Federal de São Carlos, Sorocaba, SP, Brazil. \\ *Corresponding author: Ronildo Alves Benício, e-mail: benicio.ufscar@gmail.com
}

BENÍCIO, R.A., DA SILVA, F.R. Amphibians of Vassununga State Park, one of the last remnants of semideciduous Atlantic Forest and Cerrado in northeastern São Paulo state, Brazil. Biota Neotropica. 17(1): e20160197. http:// dx.doi.org/10.1590/1676-0611-BN-2016-0197

\begin{abstract}
Although São Paulo state has one of the best known amphibian fauna in Brazil, there are still protected areas for which the species composition remains unknown. Here, we present the first species list of anuran amphibians in Vassununga State Park. This area is one of the last remnants of semideciduous Atlantic Forest and Cerrado in the northeastern region of São Paulo state, southeastern Brazil. To survey species, we visited six sites (two ponds, two streams, and two transects) in December, January, and February of 2014-2015 and 2015-2016, totalizing 18 days of field samplings at each site. We recorded 24 anuran species belonging to four families: Bufonidae ( 2 species), Hylidae (11 species), Leptodactylidae (10 species), and Microhylidae (1 species). Anurans consist mainly of generalist and widely distributed species. Although none of the species recorded are threatened with extinction according to the International Red List of Endangered Species (IUCN), four species have declining population and another three species have unknown population trends.
\end{abstract}

Keywords: Anurans, Biodiversity, Cerrado, Atlantic Forest, Species list, Conservation.

\section{Anfíbios do Parque Estadual de Vassununga, um dos últimos remanescentes de Mata Atlântica Semidecidual e Cerrado no nordeste do estado de São Paulo, Brasil}

\begin{abstract}
Resumo: Embora o estado de São Paulo tenha uma das faunas de anfíbios mais bem conhecidos do Brasil, existem áreas protegidas cuja composição de espécies ainda é desconhecida. Aqui, nós apresentamos a primeira lista de espécies de anfíbios anuros para o Parque Estadual de Vassununga. A área é um dos últimos remanescentes de Mata Atlântica Semidecidual e Cerrado no nordeste do estado de São Paulo, sudeste do Brasil. Para o inventário das espécies nós visitamos seis locais (duas lagoas, dois córregos, e duas trilhas) em dezembro, janeiro e fevereiro de 2014-2015 e 2015-2016, totalizando 18 dias de amostragens de campo em cada local. Nós registramos 24 espécies de anuros pertencentes a quatro famílias: Bufonidae (2 espécies), Hylidae (11 espécies), Leptodactylidae (10 espécies) e Microhylidae (1 espécie). A anurofauna consistiu principalmente de espécies generalistas e amplamente distribuídas. Embora nenhuma das espécies registradas esteja ameaçada de extinção segundo a IUCN, quatro espécies estão em declínio populacional e outras três espécies têm tendência populacional desconhecida.
\end{abstract}

Palavras-chave: Anuros, Biodiversidade, Cerrado, Mata Atlântica, Lista de espécies, Conservação.

\section{Introduction}

Knowing the species composition of a region is important because it is the basic dataset for ecology, systematics, biogeography, and conservation biology (e.g., Collen et al. 2008; Da Silva et al. 2012, 2014). It is recognized that Brazil has an amazing amphibian diversity (1080 species; Segalla et al. 2016), with the São Paulo state harboring $22 \%$ of known species (Rossa-Feres et al. 2011). Although, the amphibian fauna of São Paulo state is one of the best known in the country, there are still considerable herpetological survey gaps in some regions (Rossa-Feres et al. 2011). These gaps are more evident inland (i.e., northwestern and northeastern regions of the state) than in the coastal region of the state, where most surveys have been conducted (Rossa-Feres et al. 2011). For example, the increased number of anuran surveys in the last decade has contributed to records of new species in the inland areas of the state (Vasconcelos et al. 2006, Prado et al. 2008, Da Silva et al. 2009, 2010). Even protected areas such as the Vassununga State Park (created in 1970) still have not been subject to a complete faunal survey. This is worrisome because this protected area harbors one of the last remnants of Cerrado and semideciduous Atlantic Forest in the region, two biomes that are considered global hotspots for biodiversity conservation (Myers et al. 2000, Mittermeier et al. 2004). The Vassununga State Park is located in the northeastern region of the São Paulo state, which is considered one of the most deforested and fragmented regions 
in the state (Rodrigues et al. 2008). The vegetation cover has been removed for the establishment of agricultural crops, pastures and urban areas, which reduced the vegetation to $9 \%$ of its original extent (Kronka et al. 1993). Here, we provide the first list of anuran species of the Vassununga State Park, a region considered to be a geographical gap in the inventories of species in the Sao Paulo state, Brazil.

\section{Material and Methods}

\section{Study area}

The Vassununga State Park (PEV; 21 ${ }^{\circ} 43^{\prime} 05^{\prime}$ 'S, 47³5'49'W; $553 \mathrm{~m}$ above sea level) is located in the municipality of Santa Rita do Passa Quatro, northeastern São Paulo state (Figure 1). It is a Protected Area with 2071.42 ha created on October 26, 1970. The region holds different physiognomies of two Brazilian biomes, Atlantic Forest and Cerrado, which are considered global hotspots for biodiversity conservation (Myers et al. 2000, Mittermeier et al. 2004). In the PEV, the Atlantic Forest is represented by the Seasonal Semideciduous Forest sensu stricto (Veloso et al. 1991, Pennington et al. 2006), which is characterized by having $20-50 \%$ of tree species that lose part or all their leaves in the winter or during the dry season. The Cerrado is represented by three formations (Oliveira-Filho \& Ratter 2002): (i) "campo cerrado", which is formed by dry grassland scattered with shrubs and small trees; (ii) "cerrado sensu stricto", which is dominated by trees and shrubs that are often 3-8 $\mathrm{m}$ tall but still with a fair amount of herbaceous vegetation among them; and (iii) "cerradão", which is an almost closed woodland with crown cover of $50 \%$ to $90 \%$ that is made up of trees, often of 8-12 m or even taller, that cast considerable shade so that the ground layer is greatly reduced. The climate of this region is characterized by two well-defined seasons during the year: hot and wet (September to April), during which approximately $85 \%$ of the annual rainfall occurs, and a pronounced dry season (May to August), with average precipitation of only $15 \%$ of the annual rainfall. The average annual precipitation is $1,427 \mathrm{~mm}( \pm 246.83 \mathrm{SD}$, http://www.ciiagro.sp.gov. br/ciiagroonline/).

\section{Research Design and Field Methods}

We sampled anurans in two ponds (TP1 = 21 ${ }^{\circ} 43^{\prime} 9.83^{\prime \prime} \mathrm{S}, 47^{\circ} 38^{\prime} 44.5^{\prime \prime} \mathrm{W}$;

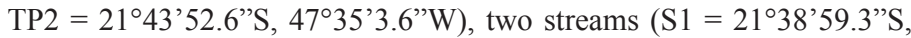
$\left.47^{\circ} 38^{\prime} 23.1^{\prime \prime} \mathrm{W} ; \mathrm{S} 2=21^{\circ} 43^{\prime} 14.6^{\prime} \mathrm{S}, 47^{\circ} 35^{\prime} 45.4^{\prime \prime} \mathrm{W}\right)$, and two transects $\left(\mathrm{T} 1=21^{\circ} 36^{\prime} 35.3^{\prime \prime S}, 47^{\circ} 37^{\prime} 22.2^{\prime \prime} \mathrm{W} ; \mathrm{T} 2=21^{\circ} 43^{\prime} 29.8^{\prime \prime} \mathrm{S}, 47^{\circ} 35^{\prime} 42.7^{\prime \prime} \mathrm{W}\right.$; Figure 2) in December, January, and February of 2014-2015 and 2015-2016 totalizing 18 days of field samplings in each site. The surveys were concentrated in this period because most anuran species from this region has reproductive activity during the rainy season (Vasconcelos \& Rossa-Feres 2005, Provete et al. 2011). We used surveys at breeding sites (Scott Jr. \& Woodward 1994) and visual encounters (Crump \& Scott Jr. 1994), two methods that are considered to be complementary (Crump \& Scott Jr. 1994, Zimmerman 1994), to record the presence of anuran at these sites. For the surveys at breeding sites, we recorded calling males from

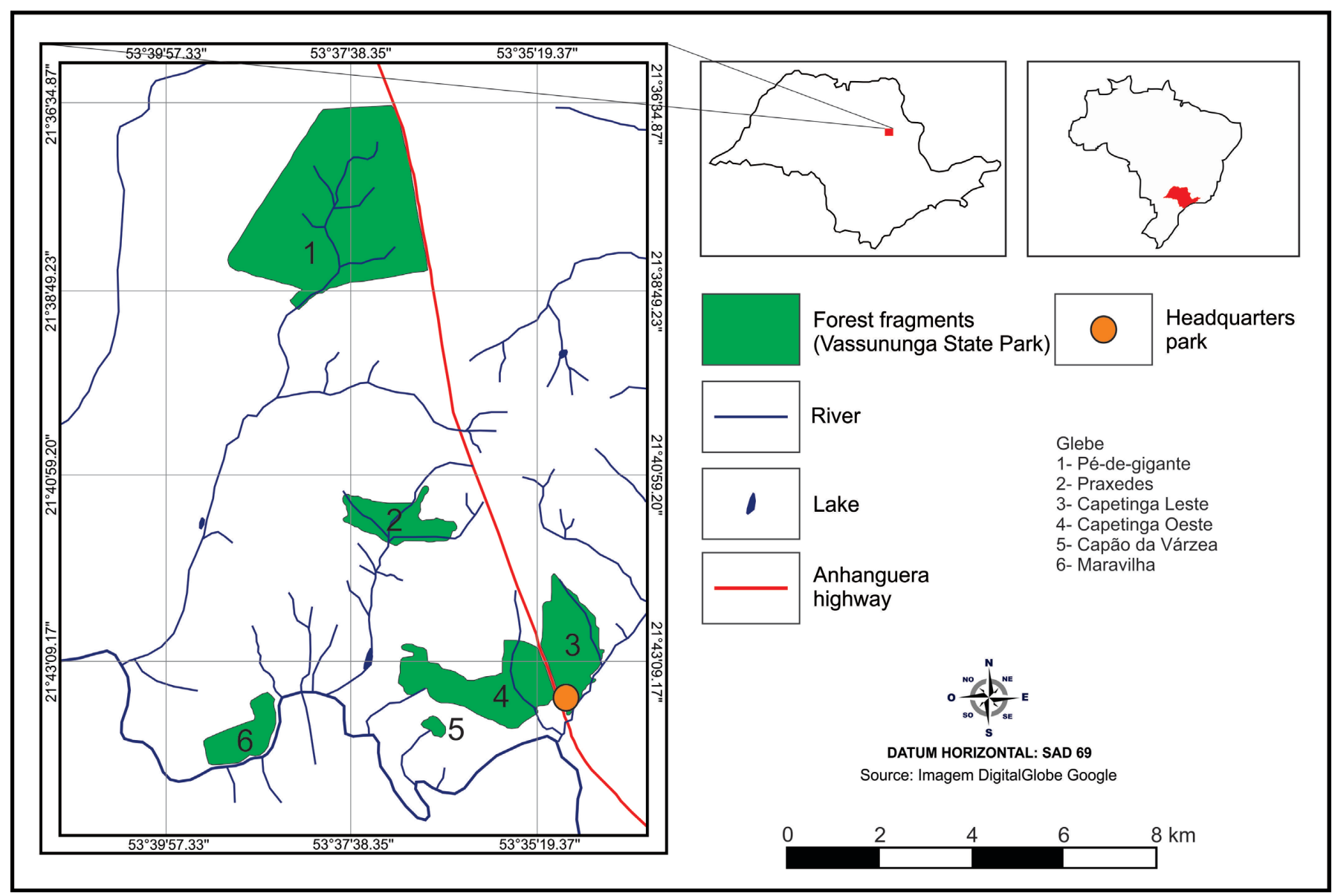

Figure 1. Maps showing the São Paulo state highlighted in Brazil (at right) and the study area highlighted in northeastern São Paulo state (at center). In detail (at left), the six isolated forest fragments (named Glebe) that comprise the total area of the Vassununga State Park. 


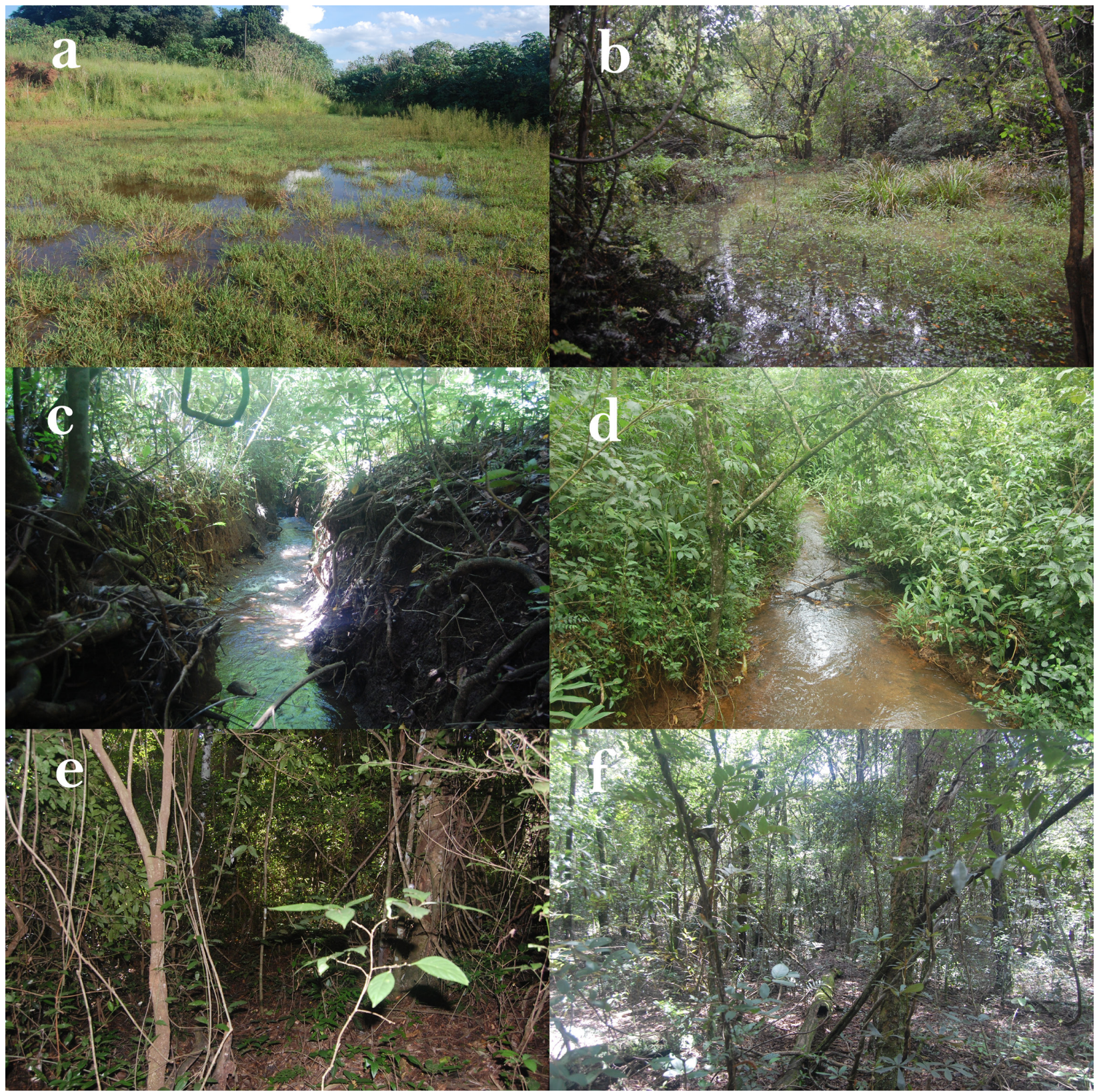

Figure 2. Sites sampled in the Vassununga State Park: (a) temporary pond in open area (TP1; $\left.21^{\circ} 43^{\prime} 9.83^{\prime \prime} \mathrm{S}, 47^{\circ} 38^{\prime} 44.5^{\prime \prime} \mathrm{W}\right)$, (b) temporary pond within gallery forest

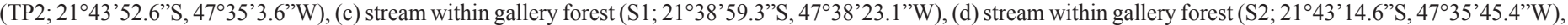

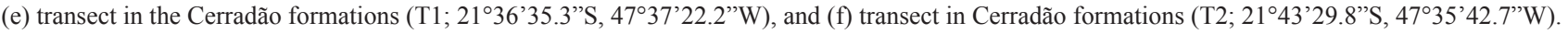

$19 \mathrm{~h}$ to $24 \mathrm{~h}$, while for visual encounter survey, we walked slowly inside the forest fragment (transects) or around ponds and streams for $30 \mathrm{~min}$ looking for individuals hidden under trunks, bromeliads, stones, branches, and leaf litter. All collected specimens were anesthetized and killed with $10 \%$ lidocaine (spray solution), fixed in $10 \%$ formaldehyde, and stored in $70 \%$ ethanol. All specimens are housed in the Coleção de Anfíbios do Departamento de Zoologia da Universidade Estadual Paulista (CFBH), municipality of Rio Claro, São Paulo state, Brazil.

\section{Data Analysis}

To assess the sampling efficiency of the surveys, we used a species accumulation curve (Gotelli \& Colwell 2001) generated from the data of incidence of anurans during the inventory period. The total number of species recorded each day was considered as a sample, totaling 18 samples.
Considering the diverse richness estimators available, we chose to use the first-order Jackknife algorithm based on its performance when compared to other estimators (Magurran 2004, Walther \& Moore 2005, Hortal et al. 2006). All analyzes were performed in R v 3.2.2 (R Core Team, 2016) using the vegan (Oksanen et al. 2016) and BiodiversityR (Kindt \& Coe 2015) packages with 1,000 randomizations. Taxonomic nomenclature follows Frost (2016). The conservation status of species was obtained from the International Red List of Endangered Species (IUCN 2015).

\section{Results and Discussion}

We recorded 24 species of anuran amphibians (Table 1, Figure 3) belonging to four families: Bufonidae (2 species), Hylidae (11 species), Leptodactylidae (10 species), and Microhylidae (1 species). Although the 


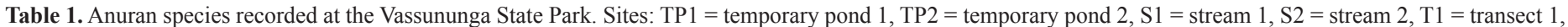
$\mathrm{T} 2=$ transect 2. Formations: $\mathrm{CE}=$ "Cerradão", GF = Gallery Forest, OA = open area. *Species with declining population according to IUCN (2015).

\begin{tabular}{|c|c|c|}
\hline Family / Species & Sites & Formations \\
\hline \multicolumn{3}{|l|}{ Family Bufonidae } \\
\hline Rhinella ornata (Spix, 1824)* & $\mathrm{T} 1$ & $\mathrm{CE}$ \\
\hline Rhinella schneideri (Werner, 1894) & $\mathrm{TP} 1, \mathrm{~S} 1, \mathrm{~T} 1$ & $\mathrm{OA}, \mathrm{GF}, \mathrm{CE}$ \\
\hline \multicolumn{3}{|l|}{ Family Hylidae } \\
\hline Dendropsophus elianeae (Napoli \& Caramaschi, 2000) & TP1 & $\mathrm{OA}$ \\
\hline Dendropsophus jimi (Napoli \& Caramaschi, 1999) & TP1 & $\mathrm{OA}$ \\
\hline Dendropsophus minutus (Peters, 1872) & TP1 & $\mathrm{OA}$ \\
\hline Dendropsophus nanus (Boulenger, 1889) & TP1, TP2 & $\mathrm{OA}, \mathrm{GF}$ \\
\hline Hypsiboas albopunctatus (Spix, 1824) & $\mathrm{TP} 1, \mathrm{TP} 2, \mathrm{~S} 2$ & $\mathrm{OA}, \mathrm{GF}$ \\
\hline Hypsiboas faber (Wied-Neuwied, 1821) & $\mathrm{TP} 1$ & $\mathrm{OA}$ \\
\hline Hypsiboas lundii (Burmeister, 1856)* & $\mathrm{T} 1, \mathrm{~S} 1$ & $\mathrm{CE}, \mathrm{GF}$ \\
\hline Itapotihyla langsdorffii (Duméril \& Bibron, 1841)* & TP2 & GF \\
\hline Scinax fuscovarius (A. Lutz, 1925) & $\mathrm{TP} 1, \mathrm{~S} 2$ & $\mathrm{OA}, \mathrm{GF}$ \\
\hline Scinax similis (Cochran, 1952) & $\mathrm{TP} 1, \mathrm{~S} 2$ & $\mathrm{OA}, \mathrm{GF}$ \\
\hline Trachycephalus typhonius (Linnaeus, 1758) & $\mathrm{TP} 1, \mathrm{TP} 2$ & $\mathrm{OA}, \mathrm{GF}$ \\
\hline \multicolumn{3}{|l|}{ Family Leptodactylidae } \\
\hline Leptodactylus fuscus (Schneider, 1799) & $\mathrm{TP} 1, \mathrm{~T} 2$ & $\mathrm{OA}, \mathrm{CE}$ \\
\hline Leptodactylus labyrinthicus (Spix, 1824) & $\mathrm{S} 2$ & GF \\
\hline Leptodactylus latrans (Steffen, 1815) & TP1 & $\mathrm{OA}$ \\
\hline Leptodactylus mystaceus (Spix, 1824) & TP2 & GF \\
\hline Leptodactylus mystacinus (Burmeister, 1861) & TP1 & $\mathrm{OA}$ \\
\hline Leptodactylus podicipinus (Cope, 1862) & TP1 & $\mathrm{OA}$ \\
\hline Physalaemus centralis Bokermann, 1962 & TP1 & $\mathrm{OA}$ \\
\hline Physalaemus cuvieri Fitzinger, 1826 & TP1 & $\mathrm{OA}$ \\
\hline Physalaemus marmoratus (Reinhardt \& Lütken, 1862) & TP1 & $\mathrm{OA}$ \\
\hline Physalaemus nattereri (Steindachner, 1863)* & TP1 & $\mathrm{OA}$ \\
\hline \multicolumn{3}{|l|}{ Família Microhylidae } \\
\hline Elachistocleis cesarii (Miranda-Ribeiro, 1920) & TP1 & $\mathrm{OA}$ \\
\hline
\end{tabular}

species accumulation curve is close to achieving asymptote, the observed species richness was smaller than the estimated species richness, indicating that more species could be recorded if we increase the sampling effort or utilize other sampling methods (e.g., pitfall traps, Figure 4).

Since Vizotto (1967), 37 anuran species have been recorded in the northwestern region of the São Paulo state (Provete et al. 2011). In this study, we recorded approximately $65 \%$ of all species that occur in the region. Only Hypsiboas albopunctatus had already been recorded at the study site (Toledo et al. 2007). The species richness observed in this study was similar to those found both in areas with predominance of Cerrado formations such as Estação Ecólogica Assis (23 species; Ribeiro-Júnior \& Bertoluci 2009), E. E. Itirapina (28 species; Brasileiro et al. 2005), E. E. Jataí (21 species; Prado et al. 2009), and E. E. Santa Bárbara (33 species; Araujo et al. 2013), and areas with a predominance of seasonal semideciduous forest such as Floresta Estadual Edmundo Navarro (21 species; Toledo et al. 2003), E. E. Caetetus (24 species; Bertoluci et al. 2007; 34 species; Brassaloti et al. 2010), and Parque Estadual Morro do Diabo (28 species; Santos et al. 2009). Although none of the recorded species is currently threatened with extinction, three species (Dendropsophus elianeae, Physalaemus centralis, and P. marmoratus) have unknown population trends, and four species (Rhinella ornata, Hypsiboas lundii, Itapotihyla langsdorffi, and Physalaemus nattereri) have declining population (IUCN 2015). Furthermore, Vasconcelos \& Doro (2016) showed that habitat loss has negative impacts in the geographic ranges of $R$. ornata, $H$. lundii, and I. langsdorffii. This fact becomes even more worrying considering that northeastern region of the São Paulo state has one of highest deforestation and fragmentation rates in the state (Rodrigues et al. 2008).
Approximately $50 \%$ of the species (Dendropsophus elianeae, D. jimi, D. minutus, Hypsiboas faber, Leptodactylus latrans, L. mystacinus, L. podicipinus, Physalaemus centralis, P. cuvieri, P. marmoratus, P. nattereri, and Elachistocleis cesarii) occurred exclusively in ponds in open areas, while 10 species (Rhinella schneideri, Dendropsophus nanus, Hypsiboas albopunctatus, H. lundii, Itapotihyla langsdorffi, Scinax fuscovarius, S. similis, Trachycephalus typhonius, Leptodactylus labyrinthicus, and L. mystaceus) occurred in streams and ponds. Hypsiboas lundii was the only species found vocalizing exclusively on streams inside gallery forest (Table 1). The large number of anuran species associated with water bodies in Cerrado and semideciduous forest fragments during the reproductive period has been demonstrated in other studies (Brasileiro et al. 2005, Bertoluci et al. 2007, Araujo et al. 2009, Santos et al. 2009, Araujo \& Almeida-Santos 2011, 2013, Valdujo et al. 2012). According to Santos et al. (2009), anuran communities from Semideciduous Atlantic Forest and Cerrado environments are more similar to each other than they are to those of Ombrophilous Forest environments. This pattern of similarity in anuran communities can be interpreted as a result of the seasonally dry climate that most likely limits the occurrence of anuran species typical of the Ombrophilous Atlantic Forest in Semideciduous Atlantic Forest and Cerrado areas (Santos et al. 2009, Da Silva et al. 2012).

Although several authors have shown that the anuran species of the Cerrado and semideciduous forest fragments are mostly associated with open areas (e.g., Brasileiro et al. 2005, Araujo et al. 2009, Santos et al. 2009, Araujo \& Almeida-Santos 2011, 2013, Valdujo et al. 2012), here we recorded $50 \%$ of species (12 species) occurring in forest areas. It should be emphasized that forests are important mesic environments, being used by adults and juveniles as refuge sites and for foraging, hibernation, and 


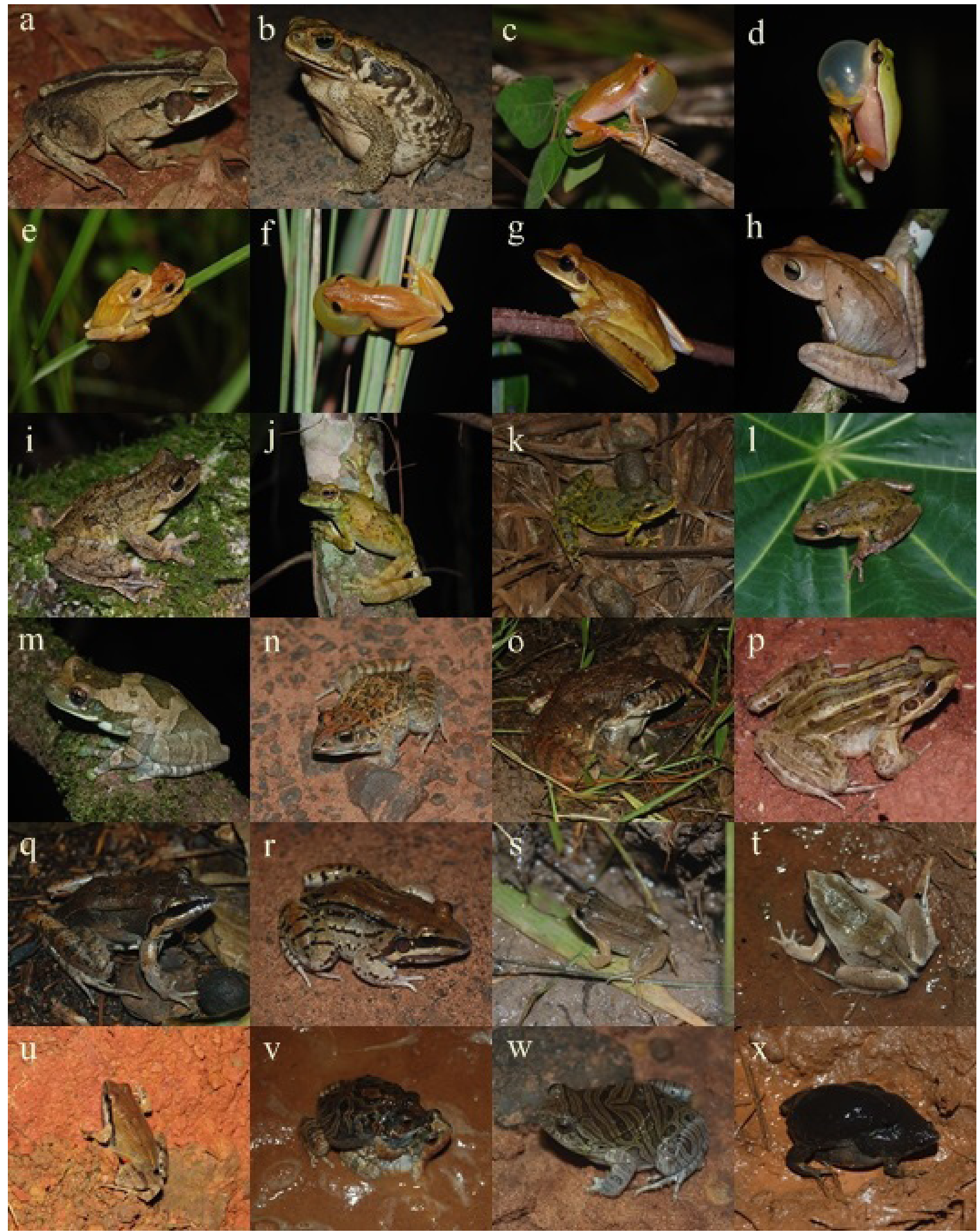

Figure 3. Anuran species recorded in the Vassununga State Park, northeastern São Paulo state, Brazil. In brackets, for each vouchered specimen we provide the acronym of the Coleção de Anfíbios do Departamento de Zoologia da Universidade Estadual Paulista, municipality of Rio Claro (CFBH) followed by the registration number and the snout-vent length $(\mathrm{SVL}) . \mathrm{a}=$ Rhinella ornata $(\mathrm{CFBH} 40455$; SVL $38.18 \mathrm{~mm}), \mathrm{b}=$ R. schneideri $(\mathrm{CFBH} 38871 ; \mathrm{SVL} 124.39 \mathrm{~mm})$, $\mathrm{c}=$ Dendropsophus elianeae, $\mathrm{d}=$ D. jimi (CFBH 40456; SVL $24.03 \mathrm{~mm}), \mathrm{e}=$ D. minutus, $\mathrm{f}=$ D. nanus $(\mathrm{CFBH} 38872$; SVL $19.07 \mathrm{~mm}), \mathrm{g}=$ Hypsiboas albopunctatus $($ CFBH $38856 ;$ SVL 52.74 mm), $\mathrm{h}=$ H. faber, $\mathrm{i}=$ H. lundii $(\mathrm{CFBH} 38870 ; \mathrm{SVL} 64.8 \mathrm{~mm}), \mathrm{j}=$ Itapotihyla langsdorffii, $\mathrm{k}=$ Scinax fuscovarius $(\mathrm{CFBH} 38862 ; \mathrm{SVL} 39.23 \mathrm{~mm}), 1=$ S. similis $(\mathrm{CFBH} 40455 ;$ SVL $38.18 \mathrm{~mm}), \mathrm{m}=$ Trachycephalus typhonius $($ CFBH 38866; SVL $31.87 \mathrm{~mm}), \mathrm{n}=$ Leptodactylus fuscus $($ CFBH $38869 ;$ SVL 33.98 mm), o = L. labyrinthicus, $\mathrm{p}=$ L. latrans, $\mathrm{q}=$ L. mystaceus, $\mathrm{r}=$ L. mystacinus $(\mathrm{CFBH} 38859 ; \mathrm{SVL} 55.95 \mathrm{~mm}), \mathrm{s}=$ L. podicipinus, $\mathrm{t}=$ Physalaemus centralis $(\mathrm{CFBH} 40457 ; \mathrm{SVL} 33.68 \mathrm{~mm})$, $\mathrm{u}=$ P. cuvieri $(\mathrm{CFBH} 38912 ; \mathrm{SVL} 28.71 \mathrm{~mm}), \mathrm{v}=$ P. marmoratus $(\mathrm{CFBH} 38865 ; \mathrm{SVL} 37.05 \mathrm{~mm}), \mathrm{w}=$ P. nattereri $(\mathrm{CFBH} 38867 ; \mathrm{SVL} 41.48 \mathrm{~mm}), \mathrm{x}=$ Elachistocleis cesarii. Photos: Ronildo Alves Benício. 


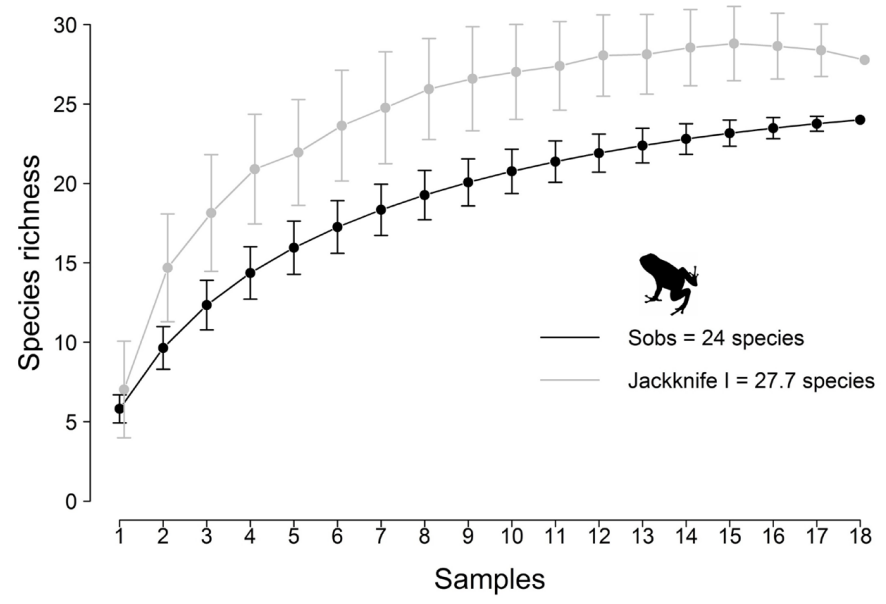

Figure 4. Species accumulation curve (black line) and Jackknife algorithm first order (gray line) representing the anuran species richness observed and estimated, respectively, based on 18 samples from December 2014 to February 2016. The dots show the mean generated by 1000 randomizations and the vertical bars indicate the standard deviation.

migration, especially during dry periods (Da Silva \& Rossa-Feres 2007). This study area is one of the most deforested and fragmented in the state, and because of the lack of biological knowledge, it is classified as a priority for fauna and flora inventories (Rodrigues et al. 2008, Rossa-Feres et al. 2011). In this sense, the species list of anurans for Vassununga State Park represents an important step in increasing the knowledge about the distribution of diversity of São Paulo state.

\section{Acknowledgements}

We thank the Instituto Chico Mendes de Conservação da Biodiversidade (ICMBio) for providing collection permits (SISBIO/3097-1) and the Instituto Florestal de São Paulo for permission to perform the study in Vassununga State Park (Proc. 260108-004.608/2014). We thank all the staff of the Vassununga State Park for helping us during fieldwork and Henrique Simão Pontes for help with the construction of the map. We also thank Diogo Borges Provete for comments on the manuscript. RAB and FRdaS thank Fundação de Amparo à Pesquisa do Estado de São Paulo (FAPESP, Proc. 2015/11821-0 and 2013/50714-0, respectively) for financial support.

\section{Author Contributions}

RAB and FRS contributed in the acquisition, analysis, data interpretation and writing of the work.

\section{References}

ARAUJO, C.O. \& ALMEIDA-SANTOS, S.M. 2011. Herpetofauna de um remanescente de Cerrado no estado de São Paulo, sudeste do Brasil. Biota Neotrop. 11(3) http://www.biotaneotropica.org.br/v11n3/pt/abstract?article+bn00511032011 (last access on 14/04/2016).

ARAUJO, C.O. \& ALMEIDA-SANTOS, S.M. 2013. Composição, riqueza e abundância de anuros em um remanescente de Cerrado e Mata Atlântica no estado de São Paulo. Biota Neotrop. 13(1): http://www.biotaneotropica.org. $\mathrm{br} / \mathrm{v} 13 \mathrm{n} 1 / \mathrm{pt} / \mathrm{abstract}$ ?inventory+bn02613012013 (last access on 14/04/2016).

ARAUJO, C.O., CONDEZ, T.H. \& SAWAYA, R.J. 2009. Anfíbios anuros do Parque Estadual das Furnas do Bom Jesus, sudeste do Brasil, e suas relações com outras taxocenoses no Brasil. Biota Neotrop. 9(2): http:// www.biotaneotropica. org.br/v9n2/pt/abstract?article+bn01109022009 (last access on 14/04/2016).

ARAUJO, C.O., CORRÊA, D.T. \& SANTOS, S.M.A. 2013. Anuros da Estação Ecológica de Santa Bárbara, um remanescente de formações abertas de Cerrado no estado de São Paulo. Biota Neotrop. 13(3): https://dx.doi.org/10.1590/ S1676-06032013000300026 (last access on 17/07/2016).

BERTOLUCI, J., BRASSALOTI, R.A., RIBEIRO-JÚNIOR, J.W., VILELA, V.M.F.N. \& SAWAKUCHI, H.O. 2007. Species composition and similarities among anuran assemblages of forest sites in southeastern Brazil. Sci. Agric. 64(4):364-374.

BRASILEIRO, C.A., SAWAYA, R.J., KIEFER, M.C. \& MARTINS, M. 2005. Amphibians of an open Cerrado fragment in southeastern Brazil. Biota Neotrop. 5(2): http://www.biotaneotropica.org.br/v5n2/ pt/abstract?article+BN00405022005 (last access on 14/04/2016).

BRASSALOTI, R.A., ROSSA-FERES, D.C. \& BERTOLUCI, J. 2010. Anuran fauna of the Semideciduous Forest of the Estação Ecológica dos Caetetus, Southeastern Brazil. Biota Neotrop. 10(1): http://www.biotaneotropica.org. br/v10n1/en/abstract?inventory+bn01810012010 (last access on 17/07/2016).

COLLEN, B., RAM, M., ZAMIM, T. \& MCRAE, L. 2008. The tropical biodiversity data gap: addressing disparity in global monitoring. Trop. Conserv. Sci. 1:75-88.

CRUMP, M.L. \& SCOTT jr, N.J. 1994. Visual encounter surveys. In Measuring and monitoring biological diversity: standard methods for amphibians (W.R. Heyer, M.A. Donnelly, R.W. McDiarmid, L.C. Hayek \& M.S. Foster (Eds.). Smithsonian Institution Press, Washington, London, p.84-92.

DA SILVA, F.R. \& ROSSA-FERES, D.C. 2007. The use of forest fragments by open-area anurans (Amphibia) in northwestern São Paulo State, Brazil. Biota Neotrop. 7:141-148. http://www.biotaneotropica.org.br/v7n2/pt/ abstract?article+bn03707022007 (last access on 19/04/2016).

DA SILVA, F.R., PRADO, V.H.M., VASCONCELOS, T.S., SANTOS, T.G. \& ROSSA-FERES, D.C. 2009. Amphibia, Anura, Microhylidae, Chiasmocleis albopunctata: Filling gap and geographic distribution map. Check List 5(2):314-316.

DA SILVA, F.R., PRADO, V.H.M. \& ROSSA-FERES, D.C. 2010. Amphibia, Anura, Hylidae, Dendropsophus melanargyreus (Cope, 1887): distribution extension, new state record and geographic distribution map. Check List 6(3):402-404.

DA SILVA, F.R., ALMEIDA-NETO, M. \& ARENA, M.V.N. 2014. Amphibian Beta Diversity in the Brazilian Atlantic Forest: Contrasting the Roles of Historical Events and Contemporary Conditions at Different Spatial Scales. PLoS ONE 9(10): e109642. doi:10.1371/journal.pone.0109642.

DA SILVA, F.R., ALMEIDA-NETO, M., PRADO, V.H.M., HADDAD, C.F.B \& ROSSA-FERES D.C. 2012. Humidity levels drive reproductive modes and phylogenetic diversity of amphibians in the Brazilian Atlantic Forest. J. Biogeogr. 39:1720-1732.

FROST, D.R. 2016. Amphibian Species of the World: an Online Reference. Version 6.0. Electronic Database accessible at http://research.amnh.org/herpetology/ amphibia/index.html. American Museum of Natural History, New York, USA (last access on 14/04/2016).

GOTELLI, N.J \& COLWELL, R.K. 2001. Quantifying biodiversity: procedures and pitfalls in the measurement and comparison of species richness. Ecol. Lett. 4(4):379-391. http://dx.doi.org/10.1046/j.1461-0248.2001.00230.x.

HORTAL, J., BORGES, P.A.V. \& GASPARE, C. 2006. Evaluating the performance of species richness estimators: sensitivity to sample grain size. J. Anim. Ecol. 75(1):274-287. http://dx.doi.org/10.1111/j.1365-2656.2006.01048.x.

IUCN. 2015. The IUCN Red List of Threatened Species (Version 2015-4). Available online at: http://www.iucnredlist.org (last access on 14/04/2016).

KINDT, R. \& COE, R. 2015. Tree diversity analysis. A manual and software for common statistical methods for ecological and biodiversity studies. World Agroforestry Centre (ICRAF), Nairobi.

KRONKA, F.J.N., MATSUKUMA, C.K., NALON, M.A., DELCALI, I.H., ROSSI, M., MATTOS, I.F.A., SHIN-IKE, M.S. \& PONTINHAS, A.A.S. 1993. Inventário florestal do Estado de São Paulo. Instituto Florestal, São Paulo.

MAGURRAN, A.E. 2004. Measuring biological diversity. Blackwell Publishing Company, Oxford.

MITTERMEIER, R.A., GIL, P.R., HOFFMAN, M., PILGRIM, J., BROOKS, T., MITTERMEIER, C.G., LAMOREUX, J. \& FONSECA, G.A.B. 2004. Hotspots 
revisited: earth's biologically richest and most endangered terrestrial ecoregions. CEMEX \& Agrupacion Sierra Madre, Cidade do México.

MYERS, N., MITTERMEIER, R.A., MITTERMEIER, C.G., FONSECA, G.A.B. \& KENT, J. 2000. Biodiversity hotspots for conservation priorities. Nature 403:853-858. http://dx.doi.org/10.1038/35002501.

OKSANEN J., BLANCHET F.G., FRIENDLY M., KINDT R., LEGENDRE P., MCGLINN D., MINCHIN P.R., O'HARA R.B., SIMPSON G.L., SOLYMOS P., STEVENS M.H.H., SZOECS E. \& WAGNER H. 2016. vegan: an R package for community ecologists. Available online at: https://cran.r-project.org/web/ packages/vegan/ (last access on 14/04/2016).

OLIVEIRA-FILHO, A.T. \& RATTER. J.A. 2002. Vegetation physiognomies and woody flora of the Cerrado biome. In The Cerrados of Brazil. Ecology and natural history of a neotropical savanna. P.S. Oliveira \& Marquis, R.J. (Eds.). Columbia University Press, New York, p.91-120.

PENNINGTON, R.T., LEWIS, G.P. \& RATTER, J.A. 2006. Neotropical Savannas and Dry Forests: Plant Diversity, Biogeography, and Conservation. Oxford: Taylor \& Francis CRC Press.

PRADO, V.H.M., BORGES, R., SILVA, F.R., TOGNOLO, T.T. \& ROSSA-FERES, D.C. 2008. Amphibia, Anura, Hylidae, Phyllomedusa azurea: Distribution extension. Check List 4(1):55-56.

PRADO, V.H.M., SILVA, F.R., DIAS, N.Y.N., PIRES, J.S.R. \& ROSSA-FERES, D.C. 2009. Anura, Estação Ecológica de Jataí, São Paulo state, southeastern Brazil. Check List 5(3):495-502.

PROVETE, D.B., GAREY, M.V., SILVA, F.R. \& ROSSA-FERES, D.C. 2011. Anurofauna do noroeste paulista: lista de espécies e chave de identificação para adultos. Biota Neotrop. 11(2): http://www.biotaneotropica.org.br/v11n2/ en/abstract?identification-key+bn01111022011 (last access on 14/04/2016).

R CORE TEAM (2016) R: A language and environment for statistical computing. R Foundation for Statistical Computing, Vienna, Austria. http://www.R-project. org. (last access on 14/04/2016).

RIBEIRO-JÚNIOR, J.W. \& BERTOLUCI, J. 2009. Anuros do cerrado da Estação Ecológica e da Floresta Estadual de Assis, sudeste do Brasil. Biota Neotrop. 9(1): http://www.biotaneotropica.org.br/v9n1/pt/abstrac t?inventory+bn02709012009 (last access on 14/04/2016)

RODRIGUES, R.R., JOLY, C.A., DE BRITO, M.C.W., PAESE, A., METZGER, J.P., CASATTI, L., NALON, M.A., MENEZES, N., IVANAUSKAS, N.M., BOLZANI, V. \& BONONI, V.L.R. 2008. Diretrizes para conservação e restauração da biodiversidade no Estado de São Paulo. FAPESP, São Paulo.

ROSSA-FERES, D.C., SAWAYA, R.J., FAIVOVICH, J., GIOVANELLI, J.G.R., BRASILEIRO, C.A., SCHIESARI, L., ALEXANDRINO, J. \& HADDAD, C.F.B. 2011. Anfíbios do Estado de São Paulo, Brasil: Conhecimento Atual e Perspectivas. Biota Neotrop. 11(1a): http://www. biotaneotropica.org.br/ v11n1a/pt/abstract?inventory+bn0041101a2011 (last access on 14/04/2016).

SANTOS, T.G., VASCONCELOS, T.S., ROSSA-FERES, D.C. \& HADDAD, C.F.B. 2009. Anurans of a seasonally dry tropical forest: Morro do Diabo State Park, São Paulo state, Brazil. J. Nat. Hist. 43(15-16):973-993. http://dx.doi. org/10.1080/00222930802702498.
SCOTT jr., N. J. \& WOODWARD, B.D. 1994. Standard techniques for inventory and monitoring: Surveys at Breeding Sites, In Measuring and Monitoring Biological Diversity. Standard Methods for Amphibians (W.R. Heyer, M.A. Donnelly, R.W. McDiarmid, L.C. Hayek \& M.S. Foster, eds). Smithsonian Institution Press, Washington, London, p.118-125.

SEGALLA, M.V., CARAMASCHI, U., CRUZ, C.A.G., GRANT, T., HADDAD, C.F.B., GARCIA, P.C.A., BERNECK, B.V.M. \& LANGONE, J. 2016. Brazilian Amphibians: List of Species. Herpetologia Brasileira 5(2):34-46.

TOLEDO, L.F., ZINA, J. \& HADDAD, C.F.B. 2003. Distribuição espacial e temporal de uma comunidade de anfíbios anuros do Município de Rio Claro, São Paulo, Brasil. Holos Envir. 3(2):136-149.

TOLEDO, L.F., RIBEIRO, R.S. \& HADDAD, C.F.B. 2007. Anurans as prey: an exploratory analysis and size relationships between predators and their prey. J. Zool. 271:170-177. http://dx.doi.org/10.1111/j.1469-7998.2006.00195.x.

VALDUJO, P.H., SILVANO, D.L., COLLI, G. \& MARTINS, M. 2012. Anuran species composition and distribution patterns in Brazilian Cerrado, a Neotropical hotspot. South Am. J. Herpetol. 7(2):63-78. http://dx.doi.org/10.2994/057.007.0209 (last access on 14/04/2016)

VASCONCELOS, T.S. \& ROSSA-FERES, D.C. 2005. Diversidade, Distribuição Espacial e Temporal de Anfíbios anuros (Amphibia, Anura) na Região Noroeste do Estado de São Paulo, Brasil. Biota Neotrop. 5(2): http://dx.doi.org/10.1590/ S1676-06032005000300010 (last access on 14/04/2016).

VASCONCELOS, T.S., SANTOS. T.G. \& HADDAD, C.F.B. 2006. Amphibia, Anura, Hylidae, Hypsiboas punctatus: distribution extension and filling distribution gaps. Check List 2(2):61-62.

VASCONCELOS, T.S. \& DORO, J.L.P. 2016. Assessing how habitat loss restricts the geographic range of Neotropical anurans. Ecol. Res. 31(6):913-921. http:// dx.doi.org/10.1007/s11284-016-1401-8.

VELOSO, H.P., RANGEL-FILHO, A.L.R. \& LIMA, J.C.A. 1991. Classificação da vegetação brasileira, adaptada a um sistema universal. Instituto Brasileiro de Geografia e Estatística, Rio de Janeiro.

VIZOTTO, L.D. 1967. Desenvolvimento de anuros da região norte-ocidental do Estado de São Paulo. Tipografia Rio Preto, São José do Rio Preto.

WALTHER, B.A. \& MOORE, J.L. 2005. The concepts of bias, precision and accuracy, and their use in testing the performance of species richness estimators, with a literature review of estimator performance. Ecography 28(6):815-829. http:// dx.doi.org/10.1111/j.2005.0906-7590.04112.x.

ZIMMERMAN, B.L. 1994. Audio strip transects. In Measuring and monitoring biological diversity: standard methods for amphibians (W.R. Heyer, M.A. Donnelly, R.W. McDiarmid, L.C. Hayek \& M.S. Foster, eds). Smithsonian Institution Press, Washington, London, p.92-97.

Received: 25/04/2016

Revised: 02/02/2017

Accepted: 03/02/2017

Published online: 02/03/2017 